[Kyiv accountant]. (electronic journal), no. 39. Available at: http://cons.parus.ua/_d.asp?r=06 STP2336fc0d693791e3afdaa8ecfab0f426 (accessed 25 January 2019).

5 Panchenko S. V., Dy`kan` V. L., Shramenko O. V., Polyakova O. M., Utkina Yu. M. (2016) Teorety`chni osnovy` organizaciyi pidpry`yemny`cz koyi diyal’nosti [Theoretical bases of the organization of business activity]. Pidpry yemny 'cztvo [Business]. Xarkiv: UkrDUZT. (in Ukrainian)

6 Panchenko S. V., Dy`kan` V. L., Shramenko O. V., Polyakova O. M., Utkina Yu. M. (2016) Realizaciya pidpry`yemny`cz koyi diyal 'nosti u suchasny`x ry`nkovy`x umovax [Implementation of entrepreneurial activity in modern market conditions]. Pidpry yemny cztvo [Business]. Xarkiv: UkrDUZT. (in Ukrainian)

7 Panchenko S. V., Dy`kan` V. L., Volovel's`ka I. V. ta in. (2017) Upravlinnya biznesom [Business management]. Xarkiv: UkrDUZT. (in Ukrainian)

8 Gabruk O., Pantelijchuk L. (2018) Zvitnist «nepry 'butkovciv» [Reporting «nonprofit»]. Oficijno pro podatky: oficijne vy`dannya derzhavnoyi fiskal noyi sluzhby
Ukrayiny [Official report on taxes: official publication of the state fiscal service of Ukraine] (electronic journal), no. 4(956). Available at: http://www.visnuk.com.ua/uk/publication/1000 07026-zvitnist-nepributkivtsiv (accessed 30 January 2019).

9 Papinova O. (2017) Buxgalters ky`x oblik $u$ nepry`butkovy`x organizaciyax [Accounting in non-profit organizations]. Uteka: shvy`dky`j poshuk nadijny`x rishen' $i$ prakty chnoyi informaciyi [Uteka: quick search for reliable solutions and practical information]. (electronic journal). Available at: https://uteka.ua/ua/publication/commerce-12sxemy-buxgalterskix-provodok-30buxgalterskij-uchet- $v$-nepribylnyxorganizaciyax (accessed 27 January 2019).

10 Tarasova M. (2013) Nalogovyy uchet $v$ nepribyl'nykh organizatsiyakh [Tax accounting in non-profit organizations]. Debetkredit [Debit-credit] (electronic journal), no. 21. Available at: Rezhim dostupa: https://online.dtkt.ua/Book/«DK»\%20№212013\%20(rus.).epub/navPoint-8 (accessed 22 January 2019).

\title{
КОНТРОЛІНГ ЕКОНОМІЧНОЇ БЕЗПЕКИ ПІДПРИЕМСТВ ПОРТОВОЇ ДІЯЛЬНОСТІ
}

\author{
Онешко С.В., к.е.н., доцент, \\ Попов I.I., махістр (ОНМУ)
}

У статті розглянуті особливості побудови системи управління економічною безпекою підприємств портової діяльності та запропоновано підхід до оиінки рівня економічної безпеки на базі системи контролінгу, який включає оцінку станів: ринку, фінансів, матеріальних ресурсів, розрахунків та інновацій. Запропонований підхід трунтується на системі показників, які характеризують діяльність підприємств портової діяльності, включає аналіз відхилень фактичних показників від планових, виявлення причин відхилень та розробку корегувальних заходів.

Ключові слова: економічна безпека, контролінг, управління, ризики, підприємства портової діяльності

(C) Онешко C.В.,

Попов I.I.

Вісник економіки транспорту і промисловості № 65, 2019 


\title{
КОНТРОЛЛИНГ ЭКОНОМИЧЕСКОЙ БЕЗОПАСНОСТИ ПРЕДПРИЯТИЙ ПОРТОВОЙ ДЕЯТЕЛЬНОСТИ
}

\author{
Онешко С.В., к.э.н., доцент, \\ Попов И.И., магистр (ОНМУ)
}

В статье рассмотрень особенности построения системь управления экономической безопасностью предприятий портовой деятельности и предложен подход к оченке уровня экономической безопасности на базе системы контроллинга, который включает оценку состояния: рынка, финансов, материальных ресурсов, расчетов и инноваџий. Предложенный подход основывается на системе показателей, характеризующих деятельность предприятий портовой деятельности, включает анализ отклонений фактических показателей от плановых, выявление причин отклонений и разработку корректирующих мероприятий.

Ключевые слова: экономическая безопасность, контроллинг, управление, риски, предприятия портовой деятельности

\section{CONTROLLING OF ECONOMIC SECURITY ENTERPRISES OF PORT ACTIVITY}

\section{Oneshko S.V., PhD in Economics, Associate Professor, Popov I.I., Master (ONMU)}

The research considers the features of construction of the economic security management system of port enterprises and proposes the use of the approach to the estimation the level of economic security on the basis of the control system. It is determined that the basis of controlling is the monitoring of the most important areas of activity: accounting, analysis and planning of results, control, analysis of the potential of the enterprise, search (liquidation) of problem areas, which allows timely response to the conditions of change of the external and internal environment of the enterprise and maintenance of its economic security. Ensuring economic security with the use of controlling is due to the timely response to the deviation of the actual implementation of plans with a view to long-term successful operation of the enterprise. Among the problems of the theoretical provision of economic security of enterprises of the port activity can be called the lack of a generally accepted method of comprehensive assessment of economic security of the enterprise. For the port activity enterprises it is proposed to use an approach to assessing the level of economic security on the basis of the control system, which includes the assessment of the following components: market condition, financial condition, material resources, state of payments and state of innovation based on the analysis of deviations of actual indicators from the plans with the identification of causes of deviations and the development of corrective measures. The proposed approach is based on a system of indicators that characterize the activities of port enterprises. It is established that each of the listed states of economic security is formed under the influence of risks that need to be defined, defended, reacted, eliminated or leveled. The targeted list of measures aimed at increasing the economic security of port activity enterprises, the introduction of which contributes to reducing costs by the value of estimated savings and increase in gross profit and financial result. activity

Key words: economic security, controlling, management, risks, enterprises of port 


\section{Постановка}

Актуальність теми

проблеми. дослідження обумовлено необхідністю створення такої системи управління підприємством, яка, нарівні 3 виконанням функції інформаційного забезпечення та аналізом показників роботи підприємства, буде надавати рекомендації керівництву в прийнятті управлінських рішень, здійснювати безперервний моніторинг стану підприємства i його зовнішнього оточення в незалежності від діяльності окремих підрозділів. Така система управління забезпечується за допомогою контролінгу, який в даному досліджені розглядається як систематичний процес перевірки фактичного виконання стандартів або планів з метою забезпечення відповідного розвитку підприємства та його довгострокового успішного функціонування.

В якості стандартів розглядаються нормативи, які розробляються підприємством самостійно 3 урахуванням галузевих особливостей діяльності та не суперечать існуючим міжнародним та національним стандартам. Так, для підприємств портової діяльності, перш за все, важливого значення мають стандарти ресурсо- та енергозберігаючих, інноваційних технологій, направлених на економічність управлінських рішень. В даному досліджені в якості стандартів економічної безпеки будемо розглядати систему показників, що характеризують стан економічної безпеки підприємств портової діяльності, які доцільно ввести у фінансовий план 3 метою їх подальшого контролю.

Використання інструментарію контролінгу при оцінці та забезпеченні економічної безпеки підприємства повинна бути частиною всеохоплюючої системи управління ризиками та розглядатися як економічно ефективна частина основного бізнесу.

Аналіз останніх досліджень і публікацій. розглядається

\section{Економічна} науковцями макроекономічної та мікроекономічної точки зору. 3 макроекономічної точки зору економічна безпека направлена на зменшення дефіциту бюджету. Мікроекономічна направленість спрямована на забезпечення загальних умов діяльності суб’єктів господарювання шляхом забезпечення наявності достатнього рівня капіталу, фінансових, матеріальних та людських ресурсів.

На макрорівні економічна безпека розглянута у багатьох дослідженнях, серед яких виділимо [1, 2]. Так, Г. Андрусеак (2015) розглядає економічну безпеку в контексті глобалізації та визначає, що «глобалізація - процес, що формує міжнародне середовище, підриває старе визначення економічної безпеки і змушує іiі перевизначити» [1].

T.M. Янковець у колективній монографії «Економічна безпека України» визначає, що «економічна безпека $\epsilon$ результатом ефективного використання потенціалу i залежить від нього. Коли економічна система знаходиться у стані захищеності, вона має можливості до власного розвитку, оскільки не витрачає зайвих зусиль на подолання будь-яких перешкод функціонуванню» [2].

На мікрорівні економічна безпека розглянута у роботах [3-6], особливості оцінки економічної безпеки підприємства 3 урахуванням галузевих особливостей приведено у наукових дослідженнях [7-10].

Взаємозв'язок економічної безпеки та контролінгу практично не розглядається науковцями. У даному напрямку можливо виділити роботи А. Мирчева i Л. Криворучко [11], С.М. Шкарлет, В.В. Бондар, В.А. Іванець [12], Д.С. Пілевич [13].

У досліджені А. Мирчева i Л. Криворучко (2013) вказується, що використання контролінгу в системі управління підприємством може поліпшити фінансовий стан підприємства через нормалізацію структури капіталу, підвищити рентабельність економічної діяльності і позитивно вплинути на всі 
активи, що, в свою чергу, забезпечує економічну безпеку фірми [11].

За думкою науковців С.М. Шкарлет, В.В. Бондар, В.А. Іванець [12] в основу контролінгу покладено відстеження найважливіших сфер діяльності: облік, аналіз та планування результатів, контроль, аналіз потенціалу підприємства, пошук «вузьких місць», зростання підприємства, стратегія просування товару на ринок, управління стратегічним розвитком. Україні просто необхідно активно використовувати контролінг як елемент підвищення рівня економічної безпеки функціонування підприємств, оскільки із зарубіжного досвіду відомо, що кращої альтернативи системі контролінгу як чіткого інструменту для обгрунтування управлінських рішень та внутрішньої системи економічного захисту поки що не знайдено.

У свою чергу, Пілевич Д.С. [13] дослідив роль контролінгу в забезпеченні фінансово-економічної

безпеки підприємства та визначив особливості формування інформаційного ресурсу у межах функціонування суб'єктів господарювання. Автором запропоновано організовувати обіг управлінської інформації на підприємствах за допомогою контролінгу, як сучасної моделі управління, при цьому акцентовано увагу на значній ролі контролінгу в забезпеченні фінансово-економічної безпеки підприємства, враховуючи його специфічні інструменти та можливості щодо правильно організованого процесу збору інформації різного типу, іiі обробки та аналітичного опрацювання.

Таким чином, використання економічного інструментарію контролінгу $\epsilon$ запорукою забезпечення економічної безпеки підприємства. Так, Османагич Беденик і Лаловац (2007) стверджують, що місія контролінгу - це впровадження та ефективне застосування певних інструментів, що сприяють прозорості бізнесу та підвищенню чутливості керівництва до внутрішніх i зовнішніх змін, що, в кінцевому підсумку, призводить до зміцнення життєздатності компанії [14].

Дослідження теорії і практики контролінгу на підприємствах міжнародного бізнесу, проведене науковцями Л. Малярець, М. Драшкович, В. Бабенко, 3. Кочуєва, О. Дорохов (2017), включає детальне пояснення як вибрати засоби контролінгу, які будуть застосовуватися на конкретному підприємстві. Авторами запропонована система контрольованих показників діяльності промислового підприємства [15].

Виділення невирішених частин загальної проблеми. Підприємства портової діяльності (ППД) $є$ складною системою, яка характеризується особливостями, пов'язаними 3 різноманіттям структури елементів (термінали, господарства, ділянки, служби) та відокремлює такі основні підсистеми, як: організаційна, технічна, технологічна, економічна, соціальна. Взаємозв'язок між даними підсистемами дозволяе раціонально використовувати трудові та матеріальні ресурси, портові площі та потужності, що $є$ умовою для підвищення ефективності роботи в межах заданих ресурсів. Виробнича і економічна системи порту, характеризуються великою кількістю зв'язків між іiі структурними елементами, а динамічність даної системи проявляється у постійних змінах виробничо-економічного стану під впливом безлічі зовнішніх i внутрішніх загроз. Всі перераховані підсистеми взаємопов'язані і тільки в своїй єдності становлять морський порт як цілісну систему, що складається з взаємозалежних частин, кожна 3 яких має свій внесок в характеристику цілого.

На теперішній час недостатньо досліджена можливість забезпечення економічної безпеки підприємства через впровадження системи та методів контролінгу в систему управління. При сучасному розвитку ринкових відносин необхідне застосування більш досконалої 
методології управління, що дозволяє адаптуватися підприємству до швидких змін умов зовнішнього середовища, а саме системи контролінгу.

Серед проблем теоретичного забезпечення економічної безпеки підприємств портової діяльності можна назвати відсутність загальновизнаного методу комплексної оцінки економічної безпеки підприємства, оскільки різні організації галузі економіки можуть використовувати різні критерії, а також порізному їх інтерпретувати. Важливо зазначити, що зарубіжні методики не зовсім пристосовані до українських реалій. Дослідження, що існують в частині оцінки рівня економічної безпеки, в більшій мірі мають макрорівневу направленість, досить актуальним $є$ питання визначення даного напрямку на мікрорівні, в розрізі суб'єктів господарювання. Крім того, запропоновані підходи до оцінки економічної безпеки не адаптовані до практичної реалізації та, в основному, не апробовані, що ускладнює визначення їх реальної доцільності.

Метою статті $є$ оцінка економічної безпеки підприємства шляхом впровадження контролінгу в систему управління підприємств портової діяльності.

Виклад основного матеріалу дослідження. Враховуючи особливості функціонування підприємств портової діяльності та тенденції, що склалися на ринку портових послуг, при побудові системи управління економічною безпекою необхідно виходити з наступного:

- існування відмітних особливостей управлінської складової економічної безпеки підприємств портової діяльності від інших галузей, «яка полягає в складності системи управління портовим господарством та ефективності іiі роботи. Безпека цієї складової буде обумовлювати імідж порту, адже вона відповідає за дотримання підприємствами портової діяльності національного та міжнародного законодавства в сфері морського транспорту» [10];
- специфічність функціонування підприємств портової діяльності, яка проявляється у використанні значних виробничих потужностей, наявності значної частки непрямих витрат та складної системи ціноутворення в ринкових умовах господарювання;

- підприємства портової діяльності входять до підприємств підвищеного екологічного ризику (наявність ймовірність розливу нафтопродуктів, несанкціонованого викиду вихлопних газів, стічних вод, небезпечних вантажів), звідси особливої важливості набуває фінансова та екологічна складові економічної безпеки за показниками можливих збитків, які напряму впливають на результати діяльності. Крім того, виникає необхідність адаптації вітчизняного законодавства у сфері природоохоронної діяльності морських портів до сучасних європейських стандартів;

- існування домінуючої частки розрахунків в іноземній валюті, що напряму впливає на присутність валютного ризику, пов'язаного 3 валютними коливаннями, які, за останні роки в Україні, є досить суттєвими;

- підвищена увага до запобігання відтоку грошових коштів у тіньовий сектор економіки, незахищеність матеріальних цінностей, можливість використання об'єктів транспорту для контрабанди;

$$
\text { - здійснення приватного }
$$

інвестування в об'єкти портової інфраструктури державної форми власності на території морського порту на підставі договорів концесії, що акцентує увагу на контролі фінансових надходжень у вигляді концесійних платежів. Так, «при оцінці вартості майна, переданого у концесію, оцінці ризиків, що виникають у результаті передачі майна та створенням підприємств портової діяльності за участю іноземних партнерів, що $є$ надзвичайно важливим в сучасному періоді для портових операторів» [9]; - посилення ролі приватного сектора в діяльності підприємств портової 
діяльності: поряд зі збільшенням економічної ефективності функціонування портового комплексу шляхом поєднання інтересів усіх учасників процесу відбувається збільшення ймовірності виникнення ризикових фінансових операцій.

Проведені теоретичні дослідження наукових розробок $[2,6,13,16]$ дозволили визначити, що економічна безпека підприємства розглядається як стан захищеності від внутрішніх та зовнішніх загроз 3 метою запобігання ризиків та фінансових втрат від використання наявних ресурсів.

Оцінка рівня економічної безпеки підприємства взагалі та підприємств портової діяльності, зокрема, проводиться 3 використанням підходів, які наведені на рис. 1.

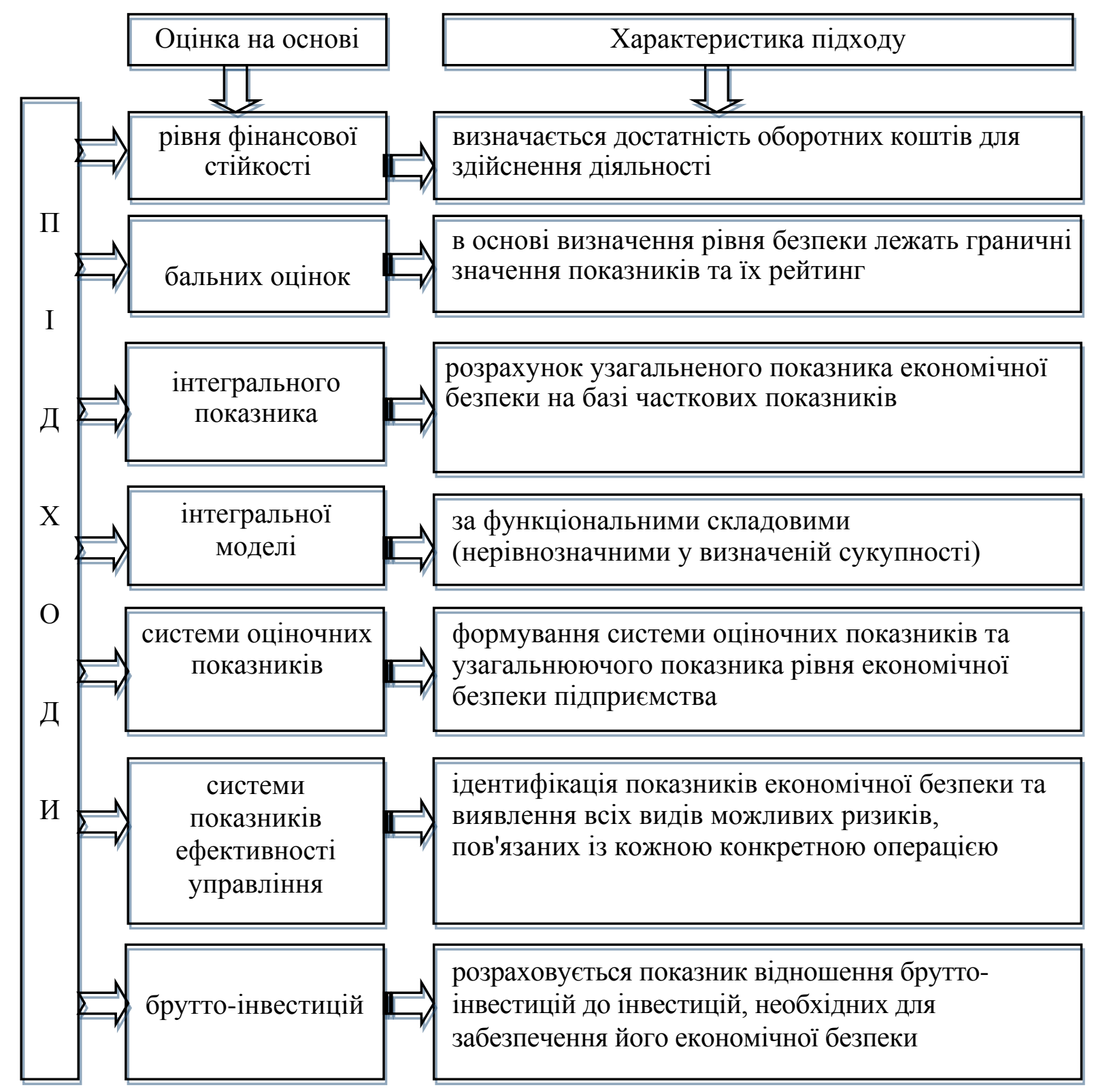

Рис. 1. Підходи до оиінки економічної безпеки підприємства Джерело: складено з використанням [3-8, 16]

Проаналізувавши наявні підходи до аналізу факторів стимуляторів та оцінки рівня економічної безпеки, для дестимуляторів, для підприємств портової узагальненого та більш комплексного діяльності пропонується використання 
підходу до оцінки їх рівня економічної безпеки на базі системи контролінгу, який включає оцінку наступних складових: стан ринку, стан фінансів, стан матеріальних ресурсів, стан розрахунків та стан інновацій.

Стан ринку - характеризує обсяги вантажопотоків, вантажообігу та вантажопереробки (за видами вантажу та напрямками вантажопотоків), тарифну політику.

Стан матеріальних ресурсів характеризує рівень використання майна та виробничих потужностей.

Стан фінансів - характеризує рівень ліквідності, платоспроможності, фінансової стійкості та ділової активності, рівень власних доходів та рентабельності діяльності, стабільність курсу валют, ціни на енергоносії, ставки комунальних послуг та податків.

Стан розрахунків - характеризує своєчасність розрахунків 3 дебіторами та кредиторами, рівень їх оборотності та тривалістю обороту.

Стан інновацій - характеризується основними факторами: непрямого впливу (законодавчі норми, податкова та амортизаційна політики, антимонопольне законодавство) та прямого впливу (дотаційне фінансування, кооперація наукових та навчальних закладів, матеріальне стимулювання працівників, створення спеціальних програм).

В якості факторів-стимуляторів розглядаються позитивні зміни в обсягах i структурі обсягів вантажопотоків та вантажопереробки, номенклатурі витрат та їх розподілу за видами послуг, використання резервів зниження витрат, оптимізація податкової та амортизаційної політик та ін. В свою чергу, до факторівдестимуляторів віднесені: відсутність сприятливих умов забезпечення конкурентоспроможності, збільшення загального рівня інфляції, неоптимальна структура власності та управління, відсутність власних джерел фінансування, наявність інформаційної асиметрії, тривале відволікання 3 обігу фінансових ресурсів в дебіторську заборгованість, недостатній внутрішній контроль та невідповідність облікової політики вимогам чинного законодавства та ін.).

Запропонований підхід грунтується на системі показників, які характеризують діяльність підприємств портової діяльності (табл. 1), базується на використанні економічного інструментарію контролінгу (аналіз результатів по відхиленням) при оцінці та забезпеченні економічної безпеки та включає аналіз відхилень фактичних показників від планових, виявлення причин відхилень та розробку корегувальних заходів.

Оцінка показників здійснюється на підставі розрахунку проміжних результатів, які дають основу для визначення показників, необхідних для використання в управлінні. Після розрахунку показників проводиться аналіз відхилень фактичних показників від планових. На підставі проведеного аналізу знаходять причини відхилень і даються рекомендації для їх усунення. Удосконалення такої системи управління може здійснюватися у напрямку використання більш коротких інтервалів для аналізу планових i фактичних показників та удосконалення управлінського обліку i звітності в структурних підрозділах.

Кожний 3 перелічених станів економічної безпеки формується під вПливом ризиків, які для підприємств портової діяльності розглянуті у багатьох дослідженнях [18-21]. Ризики для портів впливають не тільки на самі порти, а й на їхніх клієнтів та інших зацікавлених сторін. Ризики можуть включати, наприклад, фінансові втрати, крадіжки вантажу або інформації, страйки або порушення безпеки, що може призвести до зупинки порту. Ризики, пов'язані 3 портами, можуть впливати на весь ланцюжок постачання [21]. 
Таблиия 1

Оцінка стану економічної безпеки підприємств портової діяльності

\begin{tabular}{|c|c|c|c|c|c|}
\hline Показники & План & Факт & Відхилення & $\begin{array}{c}\text { Причини } \\
\text { відхилення }\end{array}$ & $\begin{array}{c}\text { Корегувальні } \\
\text { заходи }\end{array}$ \\
\hline \multicolumn{6}{|c|}{ Стан ринку } \\
\hline $\begin{array}{l}\text { Обсяги вантажопотоків, вантажообіг та } \\
\text { вантажопереробка (за видами вантажу } \\
\text { та напрямками вантажопотоків), } \\
\text { питома вага ринку, тарифні ставки }\end{array}$ & & & & & \\
\hline \multicolumn{6}{|c|}{ Стан фінансів } \\
\hline $\begin{array}{l}\text { Доходи та витрати (за видами } \\
\text { діяльності, прибуток (валовий, від } \\
\text { операційної діяльності, чистий), } \\
\text { EBITDA, мультиплікатор капіталу, } \\
\text { коефіцієнти: автономії, маневрування } \\
\text { власних коштів, абсолютної, швидкої } \\
\text { та загальної ліквідності, прихованих } \\
\text { витрат }\end{array}$ & & & & & \\
\hline \multicolumn{6}{|c|}{ Стан матеріальних ресурсів } \\
\hline $\begin{array}{l}\text { Рентабельність основних засобів, } \\
\text { фондовіддача, коефіцієнти: зносу } \\
\text { основних засобів, використання } \\
\text { портальних кранів за } \\
\text { вантажопідйомністю, інтенсивність } \\
\text { перевантажувальних робіт, питома вага } \\
\text { витрат на енергоресурси у витратах на } \\
\text { операційну діяльність }\end{array}$ & & & & & \\
\hline \multicolumn{6}{|c|}{ Стан розрахунків } \\
\hline $\begin{array}{l}\text { Оборотність та тривалість обороту } \\
\text { дебіторської та кредиторської } \\
\text { заборгованості, коефіцієнт } \\
\text { відволікання грошових коштів у } \\
\text { дебіторську заборгованість }\end{array}$ & & & & & \\
\hline \multicolumn{6}{|c|}{ Стан інновацій } \\
\hline $\begin{array}{l}\text { Витрати на інноваційну діяльність, } \\
\text { чисельність персоналу, зайнятого у } \\
\text { створенні інноваційного продукту, } \\
\text { прибуток від використання } \\
\text { інноваційної діяльності }\end{array}$ & & & & & \\
\hline
\end{tabular}

Джерело: розроблено з використанням [3, 5, 7, 8, 10, 17, 18]

Управління ризиками ускладнюється наявністю численної кількості портових операторів всередині портової зони, які можуть не належати до стратегій морського порту і тому потребують розробки власних підходів. Співпраця між різними портовими операторами та органах управління морським портом може створити концепції контролінгу. Майбутні дослідження потребуватимуть співпраці великої кількості експертів та портових операторів.

В контексті управління ризиковими операціями задля забезпечення економічної безпеки в системі контролінгу ризики 
необхідно визначати, захищати, реагувати, ліквідувати або нівелювати.

Певний інтерес представляє оцінка результатів впровадження контролінгу. Мірчев А. і Криворучко Л. [11] пропонують розрізняти прямий результат, який виникає завдяки економії коштів від впровадження контролінгу в управління (зниження витрат на заробітну плату, мінімізація штрафних санкцій, економія внаслідок зниження цін на фінансові ресурси та ін.), та мультиплікативний ефект, який з'являється у наступні роки використання контролінгу: довіра підрядників, поліпшення іміджу підприємства, підвищення кваліфікації працівників, розширення виходу на ринок.

Важливе значення в процесі підвищення рівня економічної безпеки будь-якого підприємства мають заходи економічного характеру, впровадження яких дозволяє покрити збитки та усунути причин їх виникнення, відновити ліквідність та платоспроможність, підвищити ефективність використання ресурсів, скоротити суми заборгованості та ін. Надійна система економічної безпеки включає ряд заходів, серед яких: оптимізація прямих та непрямих витрат діяльності; впровадження кошторисного фінансування; зменшення дебіторської заборгованості; удосконалення системи взаєморозрахунків; оптимізація джерел фінансування та ін.

Орієнтований перелік заходів щодо підвищення економічної безпеки підприємств портової діяльності наведено на рис. 2.

Впровадження запропонованих заходів сприяє зниженню собівартості реалізації і витрат періоду на величину економії, тим самим призводячи до збільшення валового прибутку i фінансового результату від операційної діяльності.

Висновок. В основу контролінгу покладено відстеження найважливіших сфер діяльності: облік, аналіз та планування результатів, контроль, аналіз потенціалу підприємства, пошук (ліквідація) «вузьких місць» та зростання підприємства, що дозволяє своєчасно реагувати на умови зміни зовнішнього та внутрішнього середовища діяльності підприємства та підтримки його економічної безпеки. Крім того, вірно сформована інформаційноаналітична база контролінгу на підприємстві дозволяє приймати оптимальні управлінські рішення, в тому числі i по забезпеченню економічної безпеки. На теперішній час недостатньо досліджена можливість забезпечення економічної безпеки підприємства через впровадження системи та методів контролінгу в систему управління. Забезпечення економічної безпеки 3 використанням контролінгу відбувається шляхом своєчасного реагування на відхилення фактичного виконання планів 3 метою забезпечення відповідного розвитку підприємства та його довгострокового успішного функціонування. Серед проблем теоретичного забезпечення економічної безпеки підприємств портової діяльності можна назвати відсутність загальновизнаного методу комплексної оцінки економічної безпеки підприємства, оскільки різні організації галузі економіки можуть використовувати різні критерії, а також по-різному їх інтерпретувати. Для підприємств портової діяльності пропонується використання підходу до оцінки рівня економічної безпеки на базі системи контролінгу, який включає оцінку наступних складових: стан ринку, стан фінансів, стан матеріальних ресурсів, стан розрахунків та стан інновацій на основі аналізу відхилень фактичних показників від планових з виявленням причин відхилень та розробкою корегувальних заходів. Запропонований підхід грунтується на системі показників, які характеризують функціонування підприємств портової діяльності. Встановлено, що кожний 3 перелічених станів економічної безпеки формується під впливом ризиків, які необхідно визначати, захищати, реагувати, ліквідувати або нівелювати. 


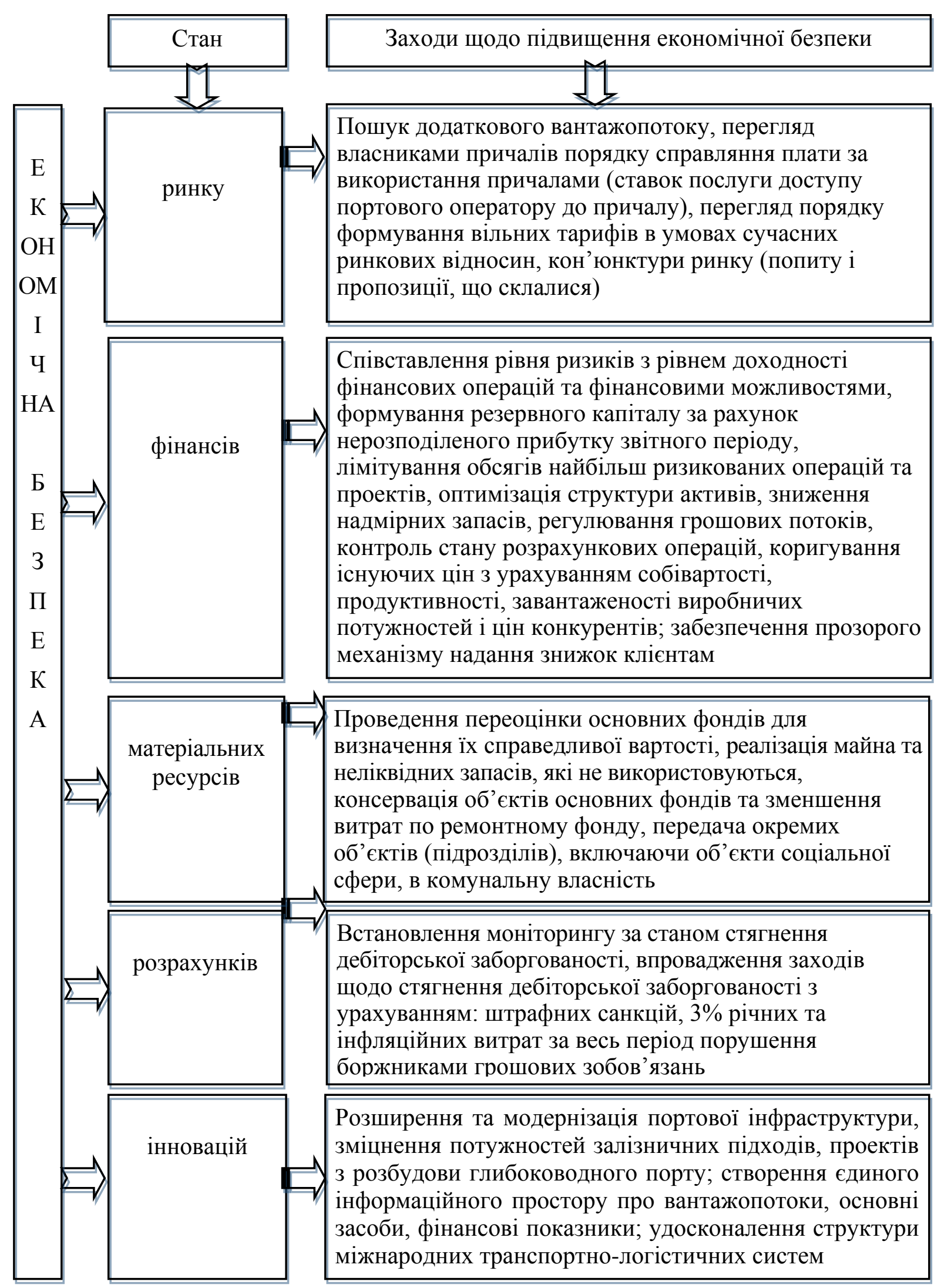

Рис. 2. Заходи щзодо підвищення економічної безпеки підприємств портової діяльності

Джерело: розроблено авторами

Вісник економіки транспорту і промисловості № 65, 2019 
Визначено орієнтований перелік заходів щодо підвищення економічної безпеки підприємств портової діяльності, впровадження яких сприяє зниженню собівартості реалізації і витрат періоду на величину економії, тим самим призводячи до збільшення валового прибутку i фінансового результату від операційної діяльності. Відкритим питанням залишається розробка рекомендацій щодо розвитку контролінгу, визначення критеріїв вибору, визначення та впровадження індикаторів оцінки економічної безпеки підприємств портової діяльності. Рішення даних питань дозволить визначити проблемні аспекти господарської діяльності, що є підгрунтям для формування інформаційноаналітичного забезпечення прийняття управлінських рішень та підвищення рівня економічної безпеки.

\section{ПЕРЕЛІК ВИКОРИСТАНИХ ДЖЕРЕЛ}

1. Andruseac Gabriel (2015) Economic security - new approaches in the context of globalization, CES Working Papers, Volume 7(2), Issue 2, pp. 232-240.

2. Економічна безпека України: монографія / Федоренко В.Г., Грищенко I.М., Новікова О.Ф. [та ін.]; за ред. В.Г. Федоренка, І.М. Грищенка, Т.С. Воронкової. - К. : ТОВ «ДКС центр», 2017. - 462 с. ISBN 978-617-7300-00-6.

3. Ильяшенко С.Н. Составляющие экономической безопасности предприятия и подходы к их оценке / С.Н. Ильяшенко. // Актуальні проблеми економіки, 2003. - № 3 (21). - C. 12-19.

4. Євдокимов Ф.I. Узагальнююча оцінка фінансової складової рівня економічної безпеки підприємства / Ф.І. Свдокимов, О.В. Мізіна, О.О. Бородіна // Екон. пр.ДонНТУ. - 2002. - Вип. 47. - С. 612.

5 Халіна В.Ю. Методичний підхід щодо оцінки рівня економічної безпеки підприємства / В.Ю. Халіна // Вісник Чернівецького торговельно-економічного інституту. - 2014. - Вип. 1. - С. 173-181.
6. Козаченко Г.В. Економічна безпека підприємства: сутність та механізм забезпечення: монографія / Г.В. Козаченко, В.П. Пономарьов, О.М. Ляшенко. - К.: Лібра, 2003. - 280 c.

7. Гришко Н.С. Формування оціночних параметрів складових економічної безпеки машинобудівного підприємства / Н.Є. Гришко // Вісник соціально-економічних досліджень. - 2013. №1(48). - С. 62-69.

8. Бойко М.О. Методичний підхід до оцінки ефективності управління економічною безпекою портового оператора / М.О. Бойко // Економічні інновації. - 2016. - C. 36-49.

9. Чиж Л.П. Особливості формування системи управління економічною безпекою портового оператора / Л.П. Чиж, М.О. Бойко // Молодий вчений. - 2016. №6(33). - С. 145-149.

10. Маляр С.Б. Функціональні складові економічної безпеки підприємства портової діяльності / С.Б. Маляр // Вісник економіки транспорту і промисловості. 2010. - C. 115-128.

11. Mirchev A. \& Kryvoruchko L. (2013) Controlling effect on the economic security of engineering enterprise conducting foreign Economic activity. Economic processes management, №1. URL: http://epm.fem.sumdu.edu.ua/download/2013_1 _8.pdf.

12. Шкарлет С.M. Контролінг у забезпеченні економічної безпеки управління підприємством / С.М. Шкарлет, В.В. Бондар, С.А. Іванець. Вісник Чернігівського державного технологічного університету: збірник. Чернігів: ЧДТУ, 2010. - №44. - С. 15-19.

13. Пілевич Д.С. Сутність фінансовоекономічної безпеки підприємства та роль контролінгу в ії забезпеченні / Д.С. Пілевич // БІЗНЕСІНФОРМ. - 2017. - № 2. - С. 337342.

14. Osmanagić Bedenik, N. and Lalovac, B. (2007), Kontroling - faktor poslovnog uspjeha na primjeru hotelskih poduzeća, Acta turistica, 19 (1), pp. 83-99.

15. Malyarets L., Draskovic M., Babenko V., Kochuyeva, Z. \& Dorokhov O. (2017) Theory and practice of controlling at 
enterprises in international business. Economic Annals-XXI, 165(5-6), 90-96.

16. Мищенко С.Н. Система обеспечения экономической безопасности организации: дис. ... канд. экон. наук: 08.00.05 / Мищенко Сергей Николаевич. Ростов н/Д, 2004. - 197 с.

17. Онешко С.В. Економіко-правові аспекти формування доходів підприємств портової діяльності / С.В. Онешко, О.О. Кукшинова // Вісник економіки транспорту і промисловості. - 2018. - № 64. - С. 300-310.

18. Oneshko S., Ilchenko S. Financial monitoring of the port industry companies on the basis of risk-oriented approach. Investment Management and Financial Innovations. Volume 14, Issue \#1, 2017. pp. 191-199.

19. Zhikhareva V. Qualitative risk assessment in port activity / V. Zhikhareva // Економічні інновації. - 2012. - Вип. 50. - С. 225-230.

20. Бойко М.О. Ризики стивідорної компанії в системі забезпечення економічної безпеки / М.О. Бойко // Молодий вчений. 2016. - №9 (36). - С. 5-10.

21. Loh Hui Shan \& Thai Vinh V. (2015) Management of disruptions by seaports: preliminary findings. Asia Pacific Journal of Marketing and Logistics. Vol 27 (1), 146-162.

\section{REFERENCES}

1. Andruseac Gabriel (2015) Economic security - new approaches in the context of globalization, CES Working Papers, Volume 7(2), Issue 2, pp. 232-240.

2. Grishchenko I.M., Novikova O.F., Voronkova T.E. (2017) Ekonomichna bezpeka Ukrajiny: monoghrafija [Economic security of Ukraine: monograph]. K: LLC "SCS center". (in Ukrainian)

$$
\text { 3. Il'yashenko S.N. }
$$

Sostavlyayushchie

$$
\text { ekonomicheskoy }
$$

bezopasnosti predpriyatiya $\mathrm{i}$ podkhody $\mathrm{k}$ ikh otsenke [Components of economic security of the enterprise and approaches to their assessment]. Actual problems of the economy. No.3(21), pp. 12-19

4. Jevdokymov F.I., Mizina O.V., Borodina O.O. (2002) Uzaghaljnjujucha ocinka finansovoji skladovoji rivnja ekonomichnoji bezpeky pidpryjemstva [Summarizing the financial component of the level of economic security of the enterprise]. Econ Ave DonNTU. Vol. 47, pp. 6-12

5 Khalina V.Ju. (2014) Metodychnyj pidkhid shhodo ocinky rivnja ekonomichnoji bezpeky pidpryjemstva [Methodical approach to assessing the level of economic security of the enterprise]. Bulletin of the Chernivtsi Trade and Economic Institute. Vol. 1, pp. 173-181.

6. Kozachenko Gh.V., Ponomarjov V.P., Ljashenko O.M. (2003) Ekonomichna bezpeka pidpryjemstva: sutnistj ta mekhanizm zabezpechennja: monoghrafija [Economic security of the enterprise: the essence and mechanism of support: a monograph]. K.: Libra. (in Ukrainian)

7. Ghryshko N.Je. (2013) Formuvannja ocinochnykh parametriv skladovykh ekonomichnoji bezpeky mashynobudivnogho pidpryjemstva [Formation of the estimated parameters of the economic safety components of the machine-building enterprise]. Bulletin of socio-economic research. Vol. 1(48), pp. 62-69

8. Bojko M.O. (2016) Metodychnyj pidkhid do ocinky efektyvnosti upravlinnja ekonomichnoju bezpekoju portovogho operatora [Methodical approach to the estimation of the efficiency of management of the economic safety of the port operator]. Economic innovation, pp. 36-49.

9. Chyzh L.P., Bojko M.O. (2016) Osoblyvosti formuvannja systemy upravlinnja ekonomichnoju bezpekoju portovogho operatora [Features of the formation of a system for managing the economic safety of the port operator]. Young scientist. Vol. 6(33), pp. 145-149

10. Maljar S.B. (2010) Funkcionaljni skladovi ekonomichnoji bezpeky pidpryjemstva portovoji dijaljnosti [Functional components of the economic security of the enterprise port activity]. The bulletin of Transport and Industry Economics. Pp. 115-128.

11. Mirchev A. \& Kryvoruchko L. (2013) Controlling effect on the economic security of engineering enterprise conducting foreign Economic activity. Economic processes management, №1. URL: http://epm.fem.sumdu.edu.ua/download/2013_1 _8.pdf.

12. Shkarlet S.M. Bondar V.V., Ivanecj S.A. (2010) Kontrolingh u zabezpechenni 
ekonomichnoji bezpeky upravlinnja pidpryjemstvom [Controlling the economic security of enterprise management]. Bulletin of Chernihiv State Technological University: collection. Vol. 44., pp. 15-19

13. Pilevych D.S. (2017) Sutnistj finansovo-ekonomichnoji bezpeky pidpryjemstva ta rolj kontrolinghu $\mathrm{v}$ jiji zabezpechenni [The essence of financial and economic security of the enterprise and the role of controlling in its provision]. BUSINESS INFORM. Vol. 2, pp. 337-342

14. Osmanagić Bedenik, N. and Lalovac, B. (2007), Kontroling - faktor poslovnog uspjeha na primjeru hotelskih poduzeća, Acta turistica, 19 (1), pp. 83-99.

15. Malyarets L., Draskovic M., Babenko V., Kochuyeva, Z. \& Dorokhov O. (2017) Theory and practice of controlling at enterprises in international business. Economic Annals-XXI, 165(5-6), 90-96.

16. Mishchenko S.N. (2004) Sistema obespecheniya ekonomicheskoy bezopasnosti organizatsii [The system of ensuring the economic security of the organization] ( $\mathrm{PhD}$ Econ). Rostov on Don: Don State Technical University.
17. Oneshko S.V., Kukshynova O.O. (2018) Ekonomiko-pravovi aspekty formuvannja dokhodiv pidpryjemstv portovoji dijaljnosti [Economic and legal aspects of the formation of incomes of enterprises of port activity]. The bulletin of Transport and Industry Economics. No. 64, pp. 300-310

18. Oneshko S., Ilchenko S. (2017) Financial monitoring of the port industry companies on the basis of risk-oriented approach. Investment Management and Financial Innovations. Volume 14, Issue \#1, pp. 191-199.

19. Zhikhareva V. (2012) Qualitative risk assessment in port activity. Economic innovation. vol. 50, pp. 225-230.

20. Bojko M.O. (2016) Ryzyky styvidornoji kompaniji v systemi zabezpechennja ekonomichnoji bezpeky [The risks of a stevedoring company in the system of economic security]. Young scientist. Vol. 9 (36), pp. 5-10.

21. Loh Hui Shan \& Thai Vinh V. (2015) Management of disruptions by seaports: preliminary findings. Asia Pacific Journal of Marketing and Logistics. Vol 27 (1), 146-162.

\title{
СИСТЕМА СТРАТЕГІЧНОГО КОНТРОЛІНГУ В АСПЕКТІ ЗАБЕЗПЕЧЕННЯ АНТИКРИЗОВОГО УПРАВЛІННЯ ПІДПРИЕМСТВОМ
}

\author{
Проценко В.М., к.е.н., зав. сектору контролю за виконанням \\ ліцензійних вимог (Департамент атестації кадрів вищої кваліфікації та \\ ліцензування Міністерства освіти і науки Украӥни)
}

В роботі проведено аналіз причин виникнення кризових явищ на всіх рівнях начіональної економіки. В рамках системи управління діяльністю підприємства розглянуто порівняльну характеристику основних елементів антикризового управління та стратегічного контролінгу. Доведено та обтрунтовано місие стратегічного контролінгу в антикризовому управлінні підприємством, як складової загальної системи управління підприємством, пропоновані інструменти стратегічного контролінгу в антикризовому управління підприємством.

Ключові слова: антикризове управління, стратегічний контролінг, криза, інструменти стратегічного контролінгу, підприємство, система управління. 